\title{
Molecular Characterization and Antimicrobial Resistance Pattern of Escherichia coli Recovered from Wastewater Treatment Plants in Eastern Cape South Africa
}

\author{
Aboi Igwaran 1,2,*(D), Benson Chuks Iweriebor ${ }^{1,2}$ and Anthony Ifeanyi Okoh ${ }^{1,2}$ (D) \\ 1 SAMRC Microbial Water Quality Monitory Center, University of Fort Hare, Alice 5700, South Africa; \\ benvida2004@yahoo.com (B.C.I.); AOkoh@ufh.ac.za (A.I.O.) \\ 2 Applied and Environmental Microbiology Research Group (AEMREG), Department of Biochemistry and \\ Microbiology, University of Fort Hare, Private Bag X1314, Alice 5700, South Africa \\ * Correspondence: aboi.igwaran@yahoo.com; Tel.: +27-780-381-271
}

Received: 19 April 2018; Accepted: 9 June 2018; Published: 12 June 2018

\begin{abstract}
Wastewater treatment plants (WWTPs) are designed to eliminate organic matter and pathogens but most WWTPs discharges antimicrobial resistance pathogens into aquatic milieu. The study aimed to examine the antibiotics resistant patterns and the presence of some resistance genes among E. coli isolates from WWTPs effluents. Water were collected from WWTPs final effluents, filtered through nitrocellulose membrane and the filter papers were placed on chromogenic agar plates, incubated for $24 \mathrm{~h}$ at $37^{\circ} \mathrm{C}$. Presumptive E. coli isolates (173) were obtained from the culture method. From the presumptive E. coli isolates screened by polymerase chain reaction (PCR), 111 isolates were positive and the positive isolates were further screened for six diarrheagenic E. coli pathotypes (EPEC, ETEC, EHEC, DAEC, EIEC, and EAEC) and from the pathotypes screened, nine isolates harboured daaE gene. The phenotypic susceptibility patterns of the 111 isolates to 12 antibiotics were determined by Kirby-Bauer disk diffusion technique. All the isolates were resistant to erythromycin and clindamycin. From the resistance genes screened, 31 isolates harboured $m c r-1$ gene and nine isolates harboured ermA gene. The study reveals that water samples recovered from the final effluents of WWTPs may likely be one of the major sources of antibiotic-resistant in Escherichia coli.
\end{abstract}

Keywords: Escherichia coli; diarrheagenic; susceptibility; WWTPs

\section{Introduction}

Wastewater treatment plants (WWTPs) serve as a vehicle of antibiotic-resistance interface between the environment and the human society. Sewage from households, hospitals, or agricultural waste contains antibiotics-resistance bacterial of human and animal origin [1]. WWTPs are generally known as "hotspots" for the occurrence, development, and dissemination of antibiotics-resistance among bacteria which can acquire this resistance gene from donor to the recipient bacteria or through selective pressure influenced by residual antibiotics-resistant microbes [2]. When these antibiotic-resistant bacteria are not completely removed from the waste water treatment plants via treatment process, they will then be discharged into aquatic and the wider terrestrial environment which will eventually enter the human system through the food chain [3]. Wastewater treatment plants receive sewage from diverse sources and bacteria from this various environments interact and exchange antibiotic-resistance genes horizontally. Wastewater treatment plants (WWTPs) are hotspots for horizontal gene transfer in bacteria allowing the spread of antibiotic-resistance gene between different bacterial species [4]. 
The discharge of treated final effluent from WWTPs into streams, ponds, earth-dams, and canals is one of the major sources of potential pathogenic contamination in surface waters [5]. Most WWTPs are designed majorly to eliminate pathogens and organic matter [6], but WWTPs discharge pathogens harbouring antimicrobial resistance (AMR) determinants into the environment, resulting in horizontal gene transfer between bacterial and other pathogens which is a global health concern with the prediction of widespread untreatable infections within the next generation [7]. Escherichia coli is one of the most used indicator organisms to monitor the microbial quality of water [8]. Disease causing E. coli is grouped into intraintestinal E. coli causing diarrhea and extraintestinal E. coli which is responsible for a range of illnesses in humans and animals [9]. Among the bacterial pathogens, diarrheagenic E. coli is the main cause of globally epidemic and endemic diarrhea [10-12]. Diarrheagenic E. coli (DAE) strains are grouped into eight pathotypes which includes enteropathogenic E. coli, enterohaemorrhagic E. coli, enterotoxigenic E. coli, enterinvasive E. coli, and enteroaggregative E. coli, diffusely-adherent E. coli, diarrhea-associated hemolytic and cytolethal distending toxin producing E. coli [13]. Diarrheagenic E. coli harbour a virulence element that is responsible for causing disease in human $[14,15]$. E. coli has been reported to be highly resistance to some antibiotics used in the treatment of diseases [16]. The occurrence of antibiotic-resistant in pathogenic bacterial strains has great health implications such as longer hospitalization [17]. The emergence of multi-resistant Gram-negative bacteria against the existing antibiotics is disappointing; nonetheless, colistin is an old antibiotic that has been reported to be effective against multi-resistant Gram-negative bacteria but was dumped in human treatment due to its neurotoxicity and nephrotoxicity effect [18]. However, the increase in the emergence of multi-resistant bacterial strains has enforced clinicians to use colistin as one of the last-resort drugs of choice to fight infections [19].

South Africa has 986 municipal water-treatment facilities [20] and about $26 \%$ of sewage is inadequately treated before being discharged into rivers [21]. However, the high level of the occurrence of bacterial pathogens in streams and rivers poses a direct health risk to the people drawing water from these surface-water sources. Studying the antimicrobial susceptibility pattern of these bacterial strains (E. coli) is significant in order to identify the shift in antibiotic resistance patterns among these pathogens and to adopt control measures that will help in preventing the spread of multidrug-resistant or resistant strains of bacteria that will help to guard clinicians on antibiotics use [22]. To our best awareness, there are few studies on the incidence of diarrheagenic E. coli and their antibiotic susceptibility pattern recovered from WWTPs in Alice and Fort Beaufort, Easter Cape South Africa. The aims of this study was to isolate E. coli from final effluent of selected WWTPs, in Alice and Fort Beaufort, determine their antibiotic susceptibility pattern, delineation of the isolates into various E. coli pathotypes and screen for the presence of resistant genes using molecular approaches.

\section{Materials and Methods}

\subsection{Study Area and Collection of Water Samples}

The study was conducted in Alice and Fort Beaufort with geographical coordinates of $32^{\circ} 47^{\prime} 0^{\prime \prime}$ South, $26^{\circ} 50^{\prime} 0^{\prime \prime}$ East, $32^{\circ} 76^{\prime} 63^{\prime \prime}$ South, $26^{\circ} 62^{\prime} 00^{\prime \prime}$ East, respectively, and both towns are located in Eastern Cape Province of South Africa. Water samples from the final effluent of the municipal WWTPs were collected once a week for three months. Samples were collected with sterile $1000 \mathrm{~mL}$ Nalgene bottles and were collected separately at three different points throughout the sampling period from the final effluents, transported on ice packs to the laboratory and processed upon arrival. The two WWTPs use activated sludge treatment technology and disinfect their final effluents by chlorination before discharging the sewage into the receiving water bodies.

\subsection{Bacterial Isolation}

After shaking, each effluent sample of $100 \mathrm{~mL}$ from the 45 water samples analyzed were filtered through nitrocellulose membrane filters $(0.45-\mu \mathrm{m}$ pore size, Millipore, Durban, South Africa) adopting 
the membrane filtration technique. The membrane filter papers were picked with a sterilized forceps, placed onto chromogenic agar plates and the plates were incubated for $24 \mathrm{~h}$ at $37^{\circ} \mathrm{C}$. After overnight incubation, 173 presumptive colonies of $E$. coli were picked, streaked onto nutrient agar plates and incubated for $24 \mathrm{~h}$ at $37^{\circ} \mathrm{C}$. Pure colonies from the nutrient agar plates were inoculated into $7 \mathrm{~mL}$ of Luria-Bertani broth, incubated for $24 \mathrm{~h}$ at $37^{\circ} \mathrm{C}$ and from which glycerol stocks were prepared and stored at $-80^{\circ} \mathrm{C}$ for future analyses.

\subsection{Extraction of Bacterial DNA}

Bacterial DNA was extracted by boiling method as described by Momtaz et al. [23] with little modification. Presumptive E. coli in glycerol stocks stored at $-80{ }^{\circ} \mathrm{C}$ were resuscitated in Luria-Bertani broth, incubated for $24 \mathrm{~h}$ at $37^{\circ} \mathrm{C}$ followed by DNA extraction as follows. For the bacteria DNA extraction, $200 \mu \mathrm{L}$ of the overnight broth was transfer into DNase free $2 \mathrm{~mL}$ microcentrifuge tubes, centrifuged at 15,000 rpm for $10 \mathrm{~min}$ and the supernatant was decanted. The pellet was re-suspended in $200 \mu \mathrm{L}$ sterile distilled water; vortexed and the cells were lysed by boiling on AccuBlock (Digital dry bath, Labnet, Staffordshire, UK) for $15 \mathrm{~min}$ at $100{ }^{\circ} \mathrm{C}$ and thereafter centrifuge at $15,000 \mathrm{rmp}$ for $5 \mathrm{~min}$. DNA-containing supernatants were transferred into another DNase free microcentrifuge tubes and were stored at $-20^{\circ} \mathrm{C}$ for future analyses.

\subsection{Molecular Confirmation of E. coli and E. coli Pathotypes}

Presumptive E. coli isolates were confirmed by polymerase chain reaction (PCR) targeting the uidA gene as earlier described by Janezic et al. [24]. The pathotypes of the confirmed E. coli isolates were determined by PCR technique making use of specific primers targeting virF gene for enteroinversive E. coli (EIEC), aafII gene for enteroaggregative E. coli (EAEC), daaE gene for diffusely adherent $E$. coli (DAEC), eae gene for enteropathogenic E. coli (EPEC), stx1 gene for enterohaemorrhagic E. coli (EHEC) and stII gene for enterotoxigenic E. coli (ETEC) as listed in Table 1. Verification of amplification of the PCR products of various reaction mixtures was carried out by resolving them in a $1.5 \%$ agarose gel electrophoresis for $35 \mathrm{~min}$ at 120 Volts in $0.5 \%$ TBE buffer stained with ethidium bromide solution. The resolved PCR products were visualized and photographed under UV light trans-illuminator (ALLIANCE 4.7) molecular Imager Gel Doc system.

Table 1. Primers sets for uidA gene of E. coli and various genes of E. coli pathotypes.

\begin{tabular}{|c|c|c|c|c|}
\hline Primer Sequence $\left(5^{\prime}-3^{\prime}\right)$ & E. coli and Pathotypes & Targeted Genes & Base Pair & References \\
\hline $\begin{array}{l}\text { F-GAACGTTGGTTAATGTGGGGTAA } \\
\text { R-ACGCGTGGTTACAGTCTTGCG }\end{array}$ & E. coli & uidA & 147 & [25] \\
\hline $\begin{array}{l}\text { F-GAACGTTGGTTAATGTGGGGTAA } \\
\text { R-TATTCACCGGTCGGTTATCAGT }\end{array}$ & $D A E C$ & $d a a E$ & 542 & [26] \\
\hline $\begin{array}{c}\text { F-AGCTCAGGCAATGAAACTTTGAC } \\
\text { R-TGGGCTTGATATTCCGATAAGTC }\end{array}$ & EIEC & virF & 618 & [26] \\
\hline $\begin{array}{l}\text { F-CACAGGCAACTGAAATAAGTCTGG } \\
\text { R-ATTCCCATGATGTCAAGCACTTC }\end{array}$ & EAEC & aafII & 378 & [26] \\
\hline $\begin{array}{l}\text { F-TCAATGCAGTTCCGT TATCAGTT } \\
\text { R-GTAAAGTCCGTTACCCCAACCTG }\end{array}$ & EPEC & eae & 482 & [26] \\
\hline $\begin{array}{l}\text { F-CAGTTAATGTGGTGGCGAAGG } \\
\text { R-CACCAGACAATGTAACCGCTG }\end{array}$ & EHEC & $s t x 1$ & 348 & [26] \\
\hline F-GCACACGGAGCTCCTCAGTC & ETEC & stII & 129 & {$[26]$} \\
\hline
\end{tabular}

\subsection{Antimicrobial Susceptibility Testing}

Antimicrobial susceptibility testing of the confirm E. coli isolates was determined by disc diffusion method on Muller-Hinton agar (MHA) plates following Clinical and Laboratory Standard Institute (CLSI) [27] guidelines. Fresh culture from the glycerol stock was streaked on nutrient agar plates, 
incubated at $37^{\circ} \mathrm{C}$ for $24 \mathrm{~h}$. Colonies were transferred into test tube of $5 \mathrm{~mL}$ of normal sterile saline adjusted to obtain turbidity matching $0.5 \mathrm{Mc}$-Farland standards. The isolates were inoculated onto MHA plates and disks impregnated with antimicrobial agents were dispensed on the inoculated plates, incubated at $37^{\circ} \mathrm{C}$ for $18-24 \mathrm{~h}$ and zones of inhibition were measured after the incubation periods. Each isolate was classified as resistant or susceptible to antimicrobial agents used while those that were intermediate were considered resistant. The commercial antibiotic discs used were: Amoxicillin $(25 \mu \mathrm{g})$, Cefuroxime $(30 \mu \mathrm{g})$, Gentamicin $(10 \mu \mathrm{g})$, Doxycycline $(30 \mu \mathrm{g})$, Ciprofloxacin $(5 \mu \mathrm{g})$, ofloxacin $(5 \mu \mathrm{g})$, Trimithoprime $(5 \mu \mathrm{g})$, Menopenem $(10 \mu \mathrm{g})$, Colistin-Sulphate $(10 \mu \mathrm{g})$, Erythromycin $(15 \mu \mathrm{g})$, Clindamycin $(2 \mu \mathrm{g})$ and Sulphamethoxazole $(25 \mu \mathrm{g})$. Table 2 show the names, concentrations and interpretation of the antibiotic discs used.

Table 2. Primers sets used in targeting various resistance genes.

\begin{tabular}{cccc}
\hline Primer Sequence $\left(\mathbf{5}^{\prime}-\mathbf{3}^{\prime}\right)$ & Targeted Genes & Base Pair $(\mathbf{b p})$ & Reference \\
\hline $\begin{array}{c}\text { F-GTTCAAGAACAATCAATACA GAG } \\
\text { R-GGATCAGGAAAAGGACATTT TAC }\end{array}$ & ermA & 421 & {$[28]$} \\
F-CGGTCAGTCCGTTTGTTC & & & \\
\hline R-CTTGGTCGGTCTGTAGGG & $M c r-1$ & 309 & {$[29]$} \\
\hline
\end{tabular}

\section{Results}

\subsection{Molecular Confirmation of E. coli Isolates}

The occurrences of 173 E. coli isolates were detected in water samples collected from the three different sampled points of the final effluent of the WWTPs and PCR analysis confirmed these findings. Among the 173 isolates screened, 111 (64.16\%) were confirmed positive for E. coli targeting the housekeeping uidA gene. Figure 1 show the confirmed molecular gel image of the amplified product of uidA (147bp) of some of the identified positive E. coli isolates.

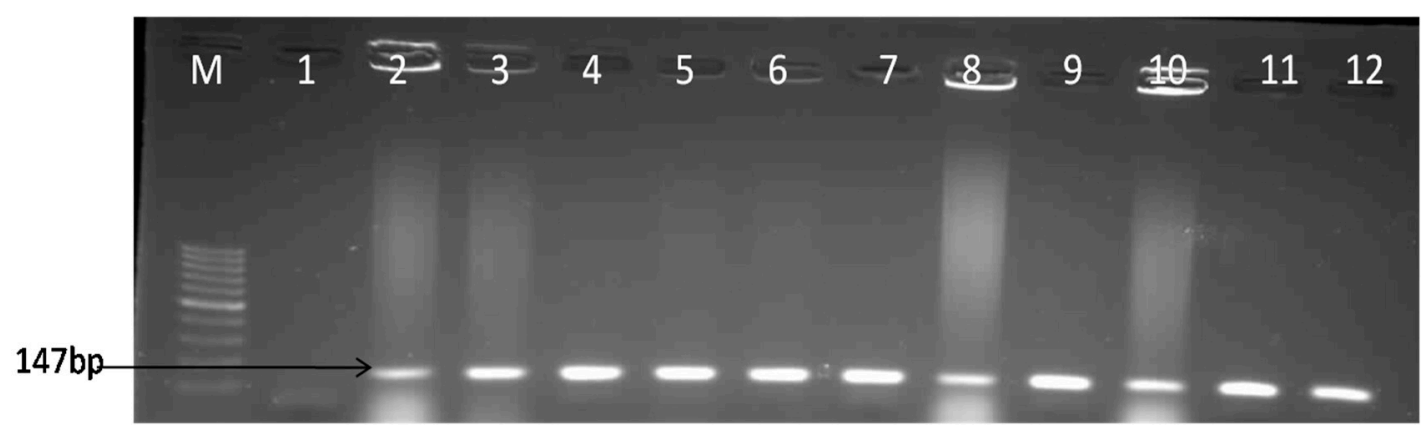

Figure 1. Gel image for the molecular confirmation of $E$. coli isolates using the $u i d A(147 \mathrm{bp})$ gene. Lane M: 100bp DNA ladder, Lane 1: Negative control, Lane 2-12 samples.

\subsection{Molecular Confirmation of E. coli Pathotypes}

Among the six E. coli pathotypes screened for by PCR technique with specific oligonucleotide primers targeting each of this diarrheagenic E. coli, only nine $(8.1 \%)$ were positive for diffusely adherent E. coli (DAEC) that harboured daaE gene while none was positive for EIEC, EPEC, EAEC, ETEC, and EHEC and the result is as shown in Table 3. Among the nine E. coli isolates that harboured daaE gene, only one isolate was susceptible to CIP, MEM, CXM, and GM while the rest isolates were all resistance to all the antibiotics. 
Table 3. Number of confirmed E. coli Pathotypes.

\begin{tabular}{ccccccc}
\hline E. coli Pathotypes & DAEC & EIEC & EPEC & EAEC & ETEC & EHEC \\
\hline Targeted genes & daaE & virF & eae & aafII & stII & st $x 1$ \\
No of positive isolates & 9 & 0 & 0 & 0 & 0 & 0 \\
\hline
\end{tabular}

\subsection{Antimicrobial Susceptibility Pattern of the Confirmed E. coli Isolates}

Antibiotic susceptibility pattern of the isolates tested against various antibiotics following Clinical and laboratory standard Institute, (CLSI) [27] Guidelines showed that clindamycin and erythromycin (100\% each) had the highest percentage resistance. The following is the frequency of the level of resistance exhibited by E. coli isolates against the antibiotics tested; clindamycin and erythromycin (100\% each), sulphamethoxazole (99\%), amoxicilin (94.5\%), doxycycline $(90 \%)$, trimithoprime $(83.7 \%)$, cefuroxime $(64.8 \%)$, ofloxacin and ciprofloxacin $(60.3 \%$ each), colistin-sulphate $(58.5 .1 \%)$, gentamicin $(52.2 \%)$, and menopenem $(48.6 \%)$ and those that showed intermediate were considered as resistant. The antimicrobial susceptibility patterns of the isolates recovered from WWTPs in the Eastern Cape Province of South Africa are shown in Figure 2.

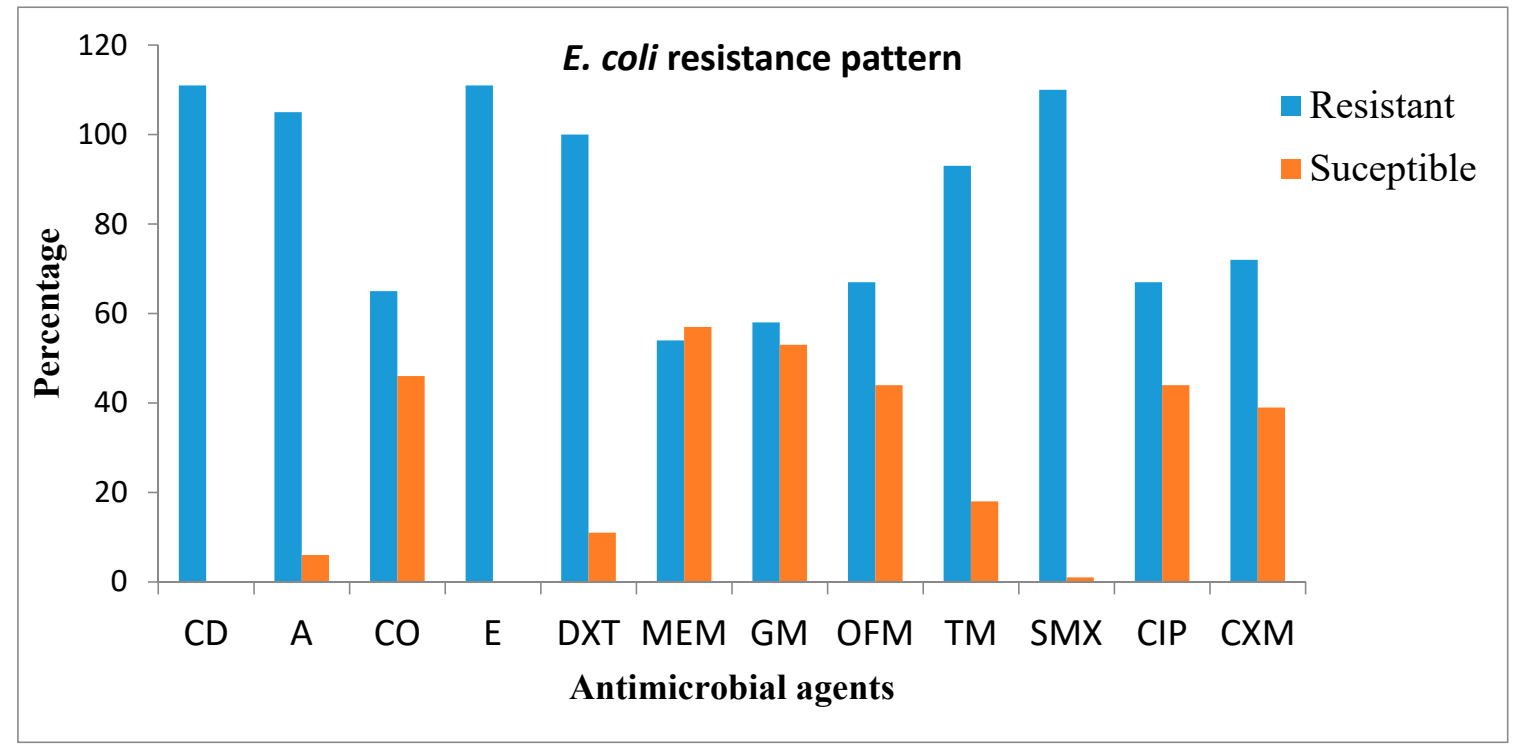

Figure 2. Antimicrobial susceptibility patterns of E. coli isolated from wastewater treatment plants (WWTPs) in the Eastern Cape South Africa. Clindamycin (CD), Amoxicillin (A), Colistin-sulphate (CO), Erythromycin (E), Doxycyline (DXT), Cefuroxime (CXM), Meropenem (MEM), Gentamicin (GM), Ofloxacin (OFX), Trimethgoprim (TM), Sulphamethaxole (SMX), and Ciprofloxacin (CIP).

\subsection{Resistance Determinants among the Isolates}

The resistant genes screened by molecular technique were ermA and mor-1. Among the 65 E. coli isolates that showed phenotypic resistance to colistin as shown in Figure 2, 31 isolates harboured mcr-1 gene, and the 111 isolates that showed phenotypic resistance to erythromycin, only nine isolates harboured ermA gene. Table 4 showed the number of confirmed E. coli isolates recovered from WWTPs that were resistance to ermA and $m c r-1$ of genes. The choice for screening for the presence of these resistance genes is because of the high phenotypic resistance in $E$. coli isolates to erythromycin and also to give an update on the efficacy of the last-resort (colistin) antibiotics. 
Table 4. Numbers of confirmed E. coli isolates resistant to ermA and $m c r-1$ genes.

\begin{tabular}{cccc}
\hline $\begin{array}{c}\text { Targeted Genes } \\
\text { Screened }\end{array}$ & $\begin{array}{c}\text { Total No of } \\
\text { Isolates Screened }\end{array}$ & $\begin{array}{c}\text { No of Isolates That Showed Phenotypic } \\
\text { Resistance to the Text Antibiotic }\end{array}$ & $\begin{array}{c}\text { No of Confirmed } \\
\text { Isolates }\end{array}$ \\
\hline$e r m A$ & 111 & 111 & 9 \\
$m c r-1$ & 111 & 65 & 31 \\
\hline
\end{tabular}

\section{Discussion}

The final effluent of wastewater treatment plants is a major vehicle of antimicrobial resistant pathogens into the aquatic environment. However, the aquatic environment also helps in the spread of antibiotic resistance genes through transfer of genetic material among these pathogens [30]. Microbiological water quality standards are majorly based on faecal indicators; though they signify a minor part of the total bacterial in aquatic environment and $E$. coli is a frequently used indicator organism used to monitor the microbial quality of water [31]. From the 173 presumptive E. coli isolates screened, 111 isolates harboured uidA gene through molecular technique. This result highlights the high occurrence of $E$. coli isolates recovered from the final effluent of the two WWTPs and this water being discharged into the environment poses a serious threat to public health and this is in support with the report of Osińska et al. [32,33]. E. coli contamination of water is, and remains a regular and persistent problem, impacting negatively on human health and national economies [34]. Diarrheagenic E. coli are the principal cause of death globally especially in developing countries where about 1.6-2.5 million deaths occur yearly as a result of diarrhea [13,35]. Among the six diarrheagenic E. coli strains profiled for from the 111 confirmed E. coli isolates, only nine $(8.1 \%)$ isolates harboured daaE gene while none was positive for EIEC, EPEC, EAEC, ETEC, and EHEC. This implies that WWTPs serves as reservoir of some diarrheagenic E. coli pathotypes and this is in agreement with the report of Mokracka et al. [36]. Study of Omar \& Barnard [37] also detected the presence of diarrheagenic E. coli from the final effluent of wastewater treatment plant and this also corroborated our findings. Another study of Sidhu et al. [38] also identified the presence of some of these diarrheagenic E. coli strains in surface water and this accentuate the global occurrence of potential diarrheagenic $E$. coli pathotypes in the aquatic environment that poses high risk of waterborne infections. Infections caused by these diarrheagenic E. coli strains are treated with antibiotics and the effectiveness of these antibiotics in the treatment of these infections is being compromised due to the increasingly emergence of resistant strains to most first-line antimicrobial agents [39].

Antimicrobial susceptibility testing is a well-known global standard enabling laboratories to help clinicians in treating infections caused by bacteria [40]. Antibiotics are commonly used therapeutic agents against infections caused by pathogenic bacterial strains; however, increase in resistance in these bacterial strains to these antibiotics need urgent actions to curtail the spread of these resistant microorganisms that poses major threats to human and animal health [41]. From the confirmed E. coli isolates that were tested against a panel of 12 commercial antimicrobial agents, the isolates exhibited different phenotypic resistance patterns against the antimicrobial agents ranging from $\mathrm{CD}$ and $\mathrm{E}$ (100\% each), SMX (99\%), A (94.5\%), DXT (90\%), TM (83.7\%), CXT (64.8\%), OFX and CIP $(60.3 \%$ each), $\mathrm{CO}(58.5 .1 \%), \mathrm{GM}(52.2 \%)$, and MEM (48.6\%). All the isolates were resistance to CD and $\mathrm{E}$ and also exhibited resistance to a wide range of antimicrobial agents as shown in Figure 2. The occurrence of antibiotic-resistant bacteria in the environment poses a serious threat to public health, adds to higher disease burden, reduces the effectiveness of these antibiotics and increases the mortality rate [33]. $\mathrm{Li}$ et al. [42] also reported high resistance rate in E. coli isolates recovered from pig faecal samples and our finding is accordance with their report. The study of Adwan et al. [43] also revealed high resistance rates (95\%) in E. coli isolate to erythromycin and this also corroborated with our result.

The aquatic milieu appears to allow antibiotic resistance genes of sewage origin to continue and spread into the environment which therefore increases the high risk of gene transfer to human and animal through food chains [44]; injection of contaminated water or through direct contact with 
infected person [45]. WWTP final effluents used as irrigation water can promote the distribution of antibiotic resistance genes into soils or water that somehow could find their ways into human system [46]. The detection of erm resistance genes by molecular method has regularly been used to monitor the loads of antibiotic resistance gene in different environments [47]. However, genetic screening of the $111 \mathrm{E}$. coli isolates that showed phenotypic resistance to erythromycin (resistance and intermediate), only nine (8.1\%) isolates harboured ermA gene and the result of the phenotypic resistance gene do not correspond with the phenotypic resistance as shown in 2. Ziembińska-Buczyńska et al. [48] and Yuan et al. [49] also reported the presence of erythromycin phenotypic resistance gene (erm gene) in E. coli recovered from wastewater treatment plant and their report is in line with our result. From the antimicrobial susceptibility test result shown in Figure 2, 65 confirmed E. coli isolates demonstrated phenotypic resistance to colistin and when these $65 \mathrm{E}$. coli isolates were screened by the PCR technique, $31(47.6 \%)$ isolates harbours $m c r-1$ gene as showed in Table 4 . Colistin sulphate is regarded as a last-resort antibiotic against multi-resistant bacterial pathogens as reported by Curcio et al. [50] and the finding from this study revealed high occurrence of colistin-resistance ( $m c r-1)$ gene which could be higher in the communities serviced by the WWTPs under investigation. E. coli developing resistance to colistin is usually associated with chromosomal mutations [51]; however, a new plasmid-mediated conveyable resistance determinant which is $m c r-1$ gene encoding for phosphoethanolamine transferase has been established as a marker for the detection of colistin resistance [29]. Quesada et al. [52] and Islam et al. [53], also reported colistin resistance E. coli isolates carrying $m c r-1$ gene and this is in concordance with our result. The continued spread of $m c r-1$ gene in E. coli and other bacterial strains will compromise the clinical usefulness of last-resort antibiotic which could result to additional antibiotic treatment failure and extensive morbidity and mortality [54]. One of the mechanism in which these bacterial that harboured these resistance genes can be transferred to human is through consumption of contaminated foods from animal origin $[55,56]$. All the isolates that showed phenotypic resistance to the test antmicrobial agents do not correspond with the number of confirmed resistance genes and this could be attributed to the fact that there are several variants of resistance determinants responsible for the observed phenotypic resistances among the isolates [57].

\section{Conclusions}

During the treatment process of WWTPs, microbes are notably reduced but vast quantities of antimicrobial agents as well as drug-resistant bacteria escaping the treatment process are channeled into aquatic milieu with treated effluents. The discharge of these treated effluents into the aquatic environment could possible increase antibiotic-resistance in E. coli thus escalating the spread of drug-resistant microbes in communities using the streams and water bodies receiving the treated effluent. The high prevalence of colistin-resistance gene in E. coli recovered from the final effluent pose a high risk to the people in this study area that depend on this surface water bodies as their major source of water and this is the first report on colistin-resistance E. coli carrying the mcr-1 gene.

Author Contributions: A.I. carried out the research and wrote the manuscript; B.C.I. and A.I.O. supervised and corrected the manuscript. All authors read and approved the final manuscript.

Funding: This research received funding from the South Africa Medical Research Council (SAMRC).

Acknowledgments: The authors are grateful to South Africa Medical Research Council (SAMRC) for financial support.

Conflicts of Interest: The authors declare no conflict of interest. 


\section{References}

1. Martínez, J.L. Environmental pollution by antibiotics and by antibiotic resistance determinants. Environ. Pollut. 2009, 157, 2893-2902. [CrossRef] [PubMed]

2. Kim, Y.; Park, J.; Seo, K. Presence of Stenotrophomonas maltophilia exhibiting high genetic similarity to clinical isolates in final effluents of pig farm wastewater treatment plants. Int. J. Hyg. Environ. Health 2018, 221, 300-307. [CrossRef] [PubMed]

3. Ivanov, V.; Stabnikov, V.; Zhuang, W.Q.; Tay, J.H.; Tay, S.T.L. Phosphate removal from the returned liquor of municipal wastewater treatment plant using iron-reducing bacteria. J. Appl. Microbiol. 2005, 98, 1152-1161. [CrossRef] [PubMed]

4. Karkman, A.; Do, T.T.; Walsh, F.; Virta, M.P.J. Antibiotic-resistance genes in waste water. Trends Microbol. 2018, 26, 220-228. [CrossRef] [PubMed]

5. Sanders, E.C.; Yuan, Y.; Pitchford, A. Fecal coliform and E. coli concentrations in effluent-dominated streams of the upper Santa Cruz Watershed. Water 2013, 5, 243-261. [CrossRef]

6. Diallo, A.A.; Bibbal, D.; Lô, F.T.; Mbengue, M.; Sarr, M.M.; Diouf, M.; Sambe, Y.; Kérourédan, M.; Alambédji, R.; Thiongane, Y.; Oswald, E.; Brugère, H. Prevalence of pathogenic and antibiotics resistant Escherichia coli from effluents of a slaughterhouse and a municipal wastewater treatment plant in Dakar. Afr. J. Microbiol. Res. 2017, 11, 1035-1042.

7. Amos, G.C.A.; Ploumakis, S.; Zhang, L.; Hawkey, P.M.; Gaze, W.H.; Wellington, E.M.H. The widespread dissemination of integrons throughout bacterial communities in a riverine system. ISME J. 2018, 12, 681-691. [CrossRef] [PubMed]

8. Wu, J.; Long, S.C.; Das, D.; Dorner, S.M. Are microbial indicators and pathogens correlated? A statistical analysis of 40 years of research. J. Water Health 2011, 9, 265-278. [CrossRef] [PubMed]

9. Ibrahim, H.B.; Tchamba, G.T.; Bagré, T.S.; Bouda, S.C.; Fody, A.M.; Kagambèga, A.; Bonkoungou, I.J.O.; Tiendrebéogo, F.; Zongo, C.; Savadogo, A.; et al. Characterization of diarrheagenic Escherichia coli isolated from raw beef, mutton, and intestines sold in Ouagadougou, Burkina Faso. J. Microbiol. Biotechnol. Food Sci. 2016, 5, 470-474. [CrossRef]

10. Bonkoungou, I.J.O.; Lienemann, T.; Martikainen, O.; Dembelé, R.; Sanou, I.; Traoré, A.S.; Siitonen, A.; Barro, N.; Haukka, K. Diarrhoeagenic Escherichia coli detected by 16-plex PCR in children with and without diarrhoea in Burkina Faso. Clin. Microbiol. Infect. 2011, 18, 901-906. [CrossRef] [PubMed]

11. Kaper, J.B.; Nataro, J.P.; Mobley, H.L. Pathogenic Escherichia coli. Nat. Rev. Microbiol. 2004, 2, $123-140$. [CrossRef] [PubMed]

12. Shetty, V.A.; Kumar, S.H.; Shetty, A.K.; Karunasagar, I.; Karunasagar, I. Prevalence and characterization of diarrheagenic Escherichia coli isolated from adults and children in Mangalore, India. J. Lab. Physicians 2012, 4, 24-29. [CrossRef] [PubMed]

13. Shabana, I.I.; Zaraket, H.; Suzuk, H. Molecular studies on diarrhea-associated Escherichia coli isolated from humans and animals in Egypt. Vet. Microbiol. 2013, 167, 532-539. [CrossRef] [PubMed]

14. Igbeneghu, O.A.; Lamikanra, A. Multiple-Resistant commensal Escherichia Coli from Nigerian Children: Potential Opportunistic Pathogens. Trop. J. Pharm. Res. 2014, 13, 423-428. [CrossRef]

15. Saeed, A.; Abd, H.; Sandstrom, G. Microbial aetiology of acute diarrhoea in children under five years of age in Khartoum. Sudan J. Med. Microbiol. 2015, 64, 432-437. [CrossRef] [PubMed]

16. Buven, G.; Bogaerts, P.; Glupczynski, Y.; Lauwer, S.; Piérard, D. Antimicrobial resistance testing of verocytotocin-producing Escherichia coli and first description of TEM-52 extended-spectrum $\beta$-lactamase in serogroup 026. Antimicrob. Agents Chem. 2010, 54, 4907-4909. [CrossRef] [PubMed]

17. Friedman, N.D.; Temkin, E.; Carmeli, Y. The negative impact of antibiotic resistance. Clin. Microbiol. Infect. 2016, 22, 416-422. [CrossRef] [PubMed]

18. Loho, T.; Dharmayanti, A. Colistin: An antibiotic and its role in multiresistant Gram-negative infections. Acta Med. Indones. 2015, 47, 157-168. [PubMed]

19. Da Silva, G.J.; Domingues, S. Interplay between colistin resistance, virulence and fitness in Acinetobacter baumannii. Antibiotics 2017, 6, 28. [CrossRef] [PubMed]

20. Hedden, S.; Cilliers, J. Parched Prospects: The Emerging Water Crisis in South Africa; African Futures Paper 11; Institute for Security Studies: Pretoria, South Africa, 2014. 
21. Turton, A. Sitting on the Horns of a Dilemma: Water as a Strategic Resource in South Africa; South African Institute of Race Relations: Johannesburg, South Africa, 2015.

22. Van Duijkeren, E.; Wannet, W.J.; Houwers, D.J.; Van Pelt, W. Antimicrobial susceptibility of Salmonella strains isolated from humans, cattle, pigs, and chickens in the Netherlands from 1984 to 2001. J. Clin. Microbiol. 2003, 41, 3574-3578. [CrossRef] [PubMed]

23. Momtaz, H.; Rahimi, E.; Moshkelani, S. Molecular detection of antimicrobial resistance genes in E. coli isolated from slaughtered commercial chickens in Iran. Vet. Med. 2012, 57, 193-197. [CrossRef]

24. Janezic, K.J.; Ferry, B.; Hendricks, E.W.; Janiga, B.A.; Johnson, T.; Murphy, S.; Roberts, M.E.; Scott, S.M.; Theisen, A.N.; Hung, K.F.; et al. Phenotypic and genotypic characterisation of Escherichia coli isolated from untreated surface waters. Open Microbiol. J. 2013, 7, 9-19. [CrossRef] [PubMed]

25. Bej, A.K.; Cesare, D.J.L.; Haff, L.; Atlas, R.M. Detection of Escherichia coli and Shigella spp. in water by using the polymerase chain reaction and gene probes for uidA. Appl. Environ. Microbiol. 1991, 57, 1013-1017. [PubMed]

26. Rajendran, P.; Ajjampur, S.S.R.; Chidambaram, D.; Chandrabose, G.; Thangaraj, B.; Sarkar, R.; Samuel, P.; Rajan, D.P.; Kang, G. Pathotypes of diarrheagenic Escherichia coli in children attending tertiary care hospital in South India. Diagn. Microbiol. Infect. Dis. 2010, 68, 117-122. [CrossRef] [PubMed]

27. Clinical and Laboratory Standards Institute. Performance Standards for Antimicrobial Susceptibility Testing; Twenty-Fourth Informational Supplement; CLSI: Wayne, PA, USA, 2014.

28. Lina, G.; Quaglia, A.; Reverdy, M.-E.; Leclercq, R.; Vandenesch, F.; Etienne, A. Distribution of genes encoding resistance to macrolides, lincosamides, and streptogramins among Staphylococci. Antimicrob. Agents Chemother. 1999, 43, 1062-1066. [PubMed]

29. Liu, Y.Y.; Wang, Y.; Walsh, T.R.; Yi, L.X.; Zhang, R.; Spencer, J.; Doi, Y.; Tian, G.; Dong, B.; Huang, X.; et al. Emergence of plasmid-mediated colistin resistance mechanism $m c r-1$ in animals and human beings in China: A microbiological and molecular biological study. Lancet Infect. Dis. 2016, 16, 161-168. [CrossRef]

30. Amos, G.C.; Gozzard, E.; Carter, C.E.; Mead, A.; Bowes, M.J.; Hawkey, P.M.; Zhang, L.; Singer, A.C.; Gaze, W.H.; Wellington, E.M. Validated predictive modelling of the environmental resistome. ISME J. 2015, 9, 1467-1476. [CrossRef] [PubMed]

31. Turolla, A.; Cattaneo, M.; Marazzi, F.; Mezzanotte, V.; Antonelli, M. Antibiotic resistant bacteria in urban sewage: Role of full-scale wastewater treatment plants on environmental spreading. Chemosphere 2018, 191, 761-769. [CrossRef] [PubMed]

32. Osińska, A.; Korzeniewska, E.; Harnisz, M.; Niestępski, S. The prevalence and characterization of antibiotic-resistant and virulent Escherichia coli strains in the municipal wastewater system and their environmental fate. Sci. Total Environ. 2017, 577, 367-375. [CrossRef] [PubMed]

33. Amaya, E.; Reyes, D.; Paniagua, M.; Calderón, S.; Rashid, M.U.; Colque, P.; Kühn, I.; Möllby, R.; Weintraub, A.; Nord, C.E. Antibiotic resistance patterns of Escherichia coli isolates from different aquatic environmental sources in León, Nicaragua. Clin. Microbiol. Infect. 2012, 18, 347-354. [CrossRef] [PubMed]

34. Canizalez-Roman, A.; Flores-Villaseñor, H.M.; Gonzalez-Nuñez, E.; Velazquez-Roman, J.; Vidal, J.E.; Muro-Amador, S.; Alapizco-Castro, G.; Díaz-Quiñonez, J.A.; León-Sicairos, N. Surveillance of diarrheagenic Escherichia coli strains isolated from diarrhea cases from children, adults and elderly at Northwest of Mexico. Front. Microbiol. 2016, 7, 1924. [CrossRef] [PubMed]

35. Bryce, J.; Boschi-Pinto, C.; Shibuya, K.; Black, R.E. WHO Child Health Epidemiology Reference Group. WHO estimates of the causes of death in children. Lancet 2005, 365, 1147-1152. [CrossRef]

36. Mokcracka, J.; Koczura, R.; Jablonska, L.; Kaznowsski, A. Phylogenetic groups, virulence genes and quinolone resistance of intergron-bearing Escherichia coli isolated from a wastewater treatment plant. Antonie van Leeuwen. 2011, 99, 817-824. [CrossRef] [PubMed]

37. Omar, K.B.; Barnard, T.G. The occurrence of pathogenic Escherichia coli in South African wastewater treatment plants as detected by multiplex PCR. Water SA 2010, 36, 172-176.

38. Sidhu, J.P.; Ahmed, W.; Hodgers, L.; Toze, S. Occurrence of virulence genes associated with diarrheagenic pathotypes in Escherichia coli isolates from surface water. Appl. Environ. Microbiol. 2013, 79, 328-335. [CrossRef] [PubMed]

39. Ishii, S.; Sadowsky, M.J. Escherichia coli in the environment: Implications for water quality and human health. Microb. Environ. 2008, 23, 101-108. [CrossRef] 
40. Rizzo, L.; Manaia, C.; Merlin, C.; Schwartz, T.; Dagot, C.; Ploy, M.C.; Michael, I.; Fatta-Kassinos, D. Urban wastewater treatment plants as hotspots for antibiotic resistant bacteria and genes spread into the environment: A review. Sci. Total Environ. 2013, 447, 345-360. [CrossRef] [PubMed]

41. Mora, A.; Blanco, E.J.; Blanco, M.; Alonso, M.P.; Dhabi, G.; Echeita, A.; González, E.A.; Bernárdez, M.I.; Blanco, J. Antimicrobial resistance of Shiga toxin (verotoxin) producing Escherichia coli O157:H7 and non-O157 strains isolated from humans, cattle, sheep and food in Spain. Res. Microbiol. 2005, 156, 793-806. [CrossRef] [PubMed]

42. Li, P.; Wu, D.; Liu, K.; Suolang, S.; He, T.; Liu, X.; Wu, C.; Wang, Y.; Lin, D. Investigation of antimicrobial resistance in Escherichia coli and enterococci isolated from Tibetan pigs. PLoS ONE 2014, 9, e95623. [CrossRef] [PubMed]

43. Adwan, K.; Jarrar, N.; Abu-Hijleh, A.; Adwan, G.; Awwad, E. Molecular characterization of Escherichia coli isolates from patients with urinary tract infections in Palestine. J. Med. Microbiol. 2014, 63, 229-234. [CrossRef] [PubMed]

44. Czekalski, N.; Sigdel, R.; Birtel, J.; Matthews, B.; Bürgmann, H. Does human activity impact the natural antibiotic resistance background? Abundance of antibiotic resistance genes in 21 Swiss lakes. Environ. Int. 2015, 81, 45-55. [CrossRef] [PubMed]

45. Chang, Q.; Wang, W.; Regev-Yochay, G.; Lipsitch, M.; Hanage, W.P. Antibiotics in agriculture and the risk to human health: How worried should we be? Evol. Appl. 2015, 8, 240-247. [CrossRef] [PubMed]

46. Wang, F.H.; Qiao, M.; Lv, Z.E.; Guo, G.X.; Jia, Y.; Su, Y.H.; Zhu, Y.G. Impact of reclaimed water irrigation on antibiotic resistance in public parks, Beijing, China. Env. Pollut. 2014, 184, 247-253. [CrossRef] [PubMed]

47. Flórez, A.B.; Alegría, Á.; Rossi, F.; Delgado, S.; Felis, G.E.; Torriani, S.; Mayo, B. Molecular identification and quantification of tetracycline and erythromycin resistance genes in Spanish and Italian retail cheeses. BioMed Res. Int. 2014, 2014, 746859. [CrossRef] [PubMed]

48. Ziembińska-Buczyńska, A.; Felis, E.; Folkert, J.; Meresta, A.; Stawicka, D.; Gnida, A.; Surmacz-Górska, J. Detection of antibiotic resistance genes in wastewater treatment plant-molecular and classical approach. Arch. Environ. Protect. 2015, 41, 23-32. [CrossRef]

49. Yuan, Q.B.; Guo, M.T.; Yang, J. Fate of antibiotic resistant bacteria and genes during wastewater chlorination: Implication for antibiotic resistance control. PLoS ONE 2015, 10, e119403. [CrossRef] [PubMed]

50. Curcioa, L.; Luppi, A.; Bonilauri, P.; Gherpelli, Y.; Pezzotti, G.; Pesciaroli, M.; Magistrali, C.F. Detection of the colistin resistance gene $\mathrm{mcr}-1$ in pathogenic Escherichia coli from pigs affected by post-weaning diarrhoea in Italy. J. Glob. Antimicrob. Resist. 2017, 10, 80-83. [CrossRef] [PubMed]

51. Olaitan, A.O.; Morand, S.; Rolain, J.M. Mechanisms of polymyxin resistance: Acquired and intrinsic resistance in bacteria. Front. Microbiol. 2014, 5, 643. [CrossRef] [PubMed]

52. Quesada, A.; Porrero, M.C.; Téllez, S.; Palomo, G.; García, M.; Domínguez, L. Polymorphism of genes encoding PmrAB in colistin-resistant strains of Escherichia coli and Salmonella enteric isolated from poultry and swine. J. Antimicrob. Chem. 2015, 70, 71-74. [CrossRef] [PubMed]

53. Islam, A.; Rahman, Z.; Monira, S.; Rahman, M.A.; Camilli, A.; George, C.M.; Ahmed, N.; Alam, M. Colistin resistant Escherichia coli carrying mor-1 in urban sludge samples: Dhaka, Bangladesh. Gut Pathog. 2017, 9, 77. [CrossRef] [PubMed]

54. Caniaux, I.; van Belkum, A.; Zambardi, G.; Poirel, L.; Gros, M.F. MCR: Modern colistin resistance. Eur. J. Clin.Microbiol. Infect. Dis. 2017, 36, 415-420. [CrossRef] [PubMed]

55. Luangtongkum, T.; Jeon, B.; Han, J.; Plummer, P.; Logue, C.M.; Zhang, Q. Antibiotic resistance in Campylobacter: Emergence, transmission and persistence. Future Microbiol. 2009, 4, 189-200. [CrossRef] [PubMed]

56. Kumar, P.; Kumar, A. Prevalence and antibiotic resistance pattern of Campylobacter species in foods of animal origin. Vet. World 2014, 7, 681-684.

57. Iweriebor, B.C.; Iwu, C.J.; Obi, L.C.; Nwodo, U.U.; Okoh, A.I. Multiple antibiotic resistances among Shiga toxin producing Escherichia coli O157 in feces of dairy cattle farms in Eastern Cape of South Africa. BMC Microbiol. 2015, 15, 213. [CrossRef] [PubMed]

(C) 2018 by the authors. Licensee MDPI, Basel, Switzerland. This article is an open access article distributed under the terms and conditions of the Creative Commons Attribution (CC BY) license (http://creativecommons.org/licenses/by/4.0/). 